\title{
制御用計算機のアナログ入カ精度と コモン・モード電圧の関係 ${ }^{\dagger}$
}

\author{
化田周 一* \\ The Relation between the Common Mode Voltage and the \\ Analog Input Accuracy in Process Control Computer
}

\author{
Shuichi NitTA*
}

One of the causes of decreasing the analog input accuracy of the process control computer is the common mode voltage induced commonly on a pair of signal lines. The common mode voltage is converted to the normal mode voltage (appearing as the differential voltage between a pair of signal lines) by the influence of the unbalance resistance existing in the pair of signal lines and the leakage impedance between the signal lines and the ground: when there are open scanner switches in parallel with the input signal lines.

The normal mode voltage is superposed on the signal voltage and causes an error.

The normal mode voltage, if converted at the signal source side from the input scanner, can be eliminated by a low pass filter, if converted at the amplifier side from the input scanner, cannot effectively be eliminated by the low pass filter.

In this paper, the relation between the common mode voltage and the input accuracy is discussed, in view of the following three points.

1) Referring to the equations for the conversion of the common mode voltage into the normal mode voltage, the double mixed shielding method is introduced, which is effective for decreasing the common mode voltage with the electro-magnetic shield by the method of two points' earth shielding.

The double mixed shielding method is also effective for making large the common mode rejection ratio with only electrostatic shield by the method of one point

†第 4 回計測自動制御学会学術講演会で発表 (昭 40.7) 第 15 回自動制御連合講演会で発表（昭 47.11）

* 三菱電機(株) 鎌倉市上町屋 325

* Mitsubishi Electric Co. Ltd., Kamakura (Received March 4, 1975) earth shielding.

2) The block switches' effect for the common mode rejection ratio and the optimum number of block switches is discussed.

(The block switch, is inserted in series with the specified number of scanner switches.)

3) The design method for the amplifier's settling time is discussed, in view of the relation between the scanning speed and the settling time, and between the induced noise rejection by clock pulse and the settling time.

\section{1.ばじめに}

計算制御を実施するうえで，基本的に重要なととは 正確にプラントの状態を知るととである．特にアナロ グ入力信号は信号線にのった雑音が精度に影響を及ば すので問題が大きい(1)．制御用計算機で扱うアナログ 入力の精度に影響を及ぼすむのとしては，増幅器のド リフト, $\mathrm{AD}$ 変換器の精度, 検出器の精度などの装置 固有の精度が基本にある.

しかし，制御用計算機で扱うアナログ入力は Fig. 1 のブロック図执よび Fig. 2 の概念図に示すように， 信号源加計算機入力端子への数 百 $\mathrm{m}$ 程度の配線上

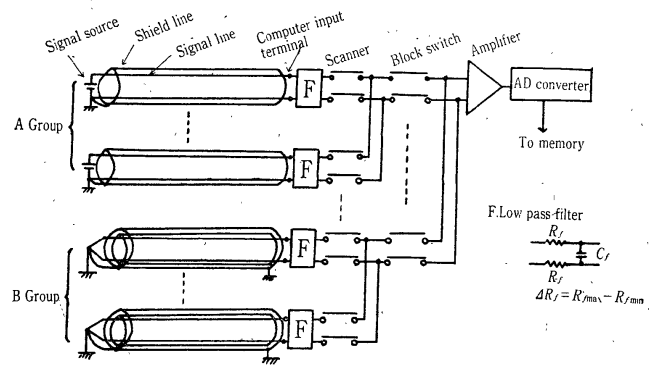

Fig. 1 Typical simplified analog input system, configuration 
で，電力線からの誘導により 2 線に共通にのったコモ ン・モード電圧 (CMV) が, 2 線の不平衡抵抗, 対地 漏洩インピーダンス, 'ズキャナなどの影響で 2 線間の 差動電圧であるノーマル・モード電圧 (NMV) 亿変換 され，信号電庄に重畳して，誤差となる2 ${ }^{2)}$ ) ので装置 固有の精度以外のととを問題にしなければならない.

筆者は先に，上記の問題を信号源でしゃへい線と信 号線の - 側 (あるいは + 側) が接地された信号源 1 点接地方式の制御用計算機アナログ入力信号線の等 価回路として取上げ，CMV と NMV の関係（コモ ン・モード除去比，CMRR $=20 \log _{10}|\mathrm{CMV} / \mathrm{NMV}|$ ) を考察した ${ }^{22} . \mathrm{CMV}$ を接地電位差として扱い, 集中 定数回路とみなすととによって CMRR を導き出した

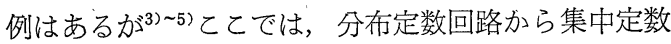
回路任置きかえる方式によってつぎの考察を行う.

まず，文献 2) の方式を拡張し，しゃへい線を信号 源と計算機入力端子の両所で接地した 2 点接地方式の 等価回路, CMRR の導き出し, および 2 重しゃへい 線を使用し， 1 点接地方式と 2 点接地方式の長所を採 用した 2 重しゃへい混合接地方式の提案と，ての方式 のCMRR の導き出し，つぎに CMRR 特性式を使っ て各方式の比較検討を行う.

つぎに，CMRR 向上の方式として，信号線の対地 漏洩インピーダンスを大きくするブロック・スイッチ の採用，およびブロック・スイッチを使用した場合の CMRR 特性式の変更を導き出し，その効果を明らか にし，最適ブロック数の設定を行う.

最後に, 計算機内部で誘導される雑音, スキャニン グ速度を対象にし，所要精度を得るための，大力増幅 器の時定数の設計法を述べる.

\section{2. 各種しゃへい方式の比較 (2 重しゃへい混合接地方式)}

制御用計算機のアナログ入力信号は，Fig.1 亿示す ように, 2 線間の差動電圧として計算機端子へ運ばれ, NMV 除去のためのローパス・フィルタを通り, 多数 の点のうちの 1 点を選択するためのスキャナを通って 信号增幅と信号源～計算機間の絶縁のために設けられ た直流增幅器を通り, $\mathrm{AD}$ 変換器へ与えられる. 信号 線は通常，しゃへい線を用い，信号源で 1 点接地され る.

信号源 1 点接地の方式は, 静電しゃへいの効果と CMRR を大きくする効果がある，すなわち，しゃへ い線が接地されているので, 静電誘導による CMV が 電磁誘導による CMV に比較して十分小さいので，電 磁誘導による CMV のみを考え，ての CMV が信号

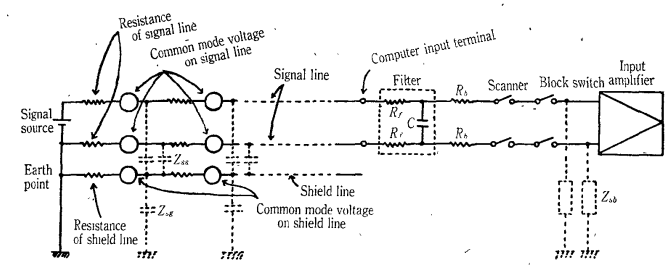

$Z_{\text {ss }}$ : leakage impedance between signal line and shield line

$Z_{s g}$ : leakage impedance between shield line and ground

$Z_{s b}$ : leakage impedance between signal line and ground rear the computer input terminal

$R_{b}$ : resistance of signal line rear the computer input terminal

Fig. 2 Conception of common mode voltage versus normal mode voltage by inductive pick up

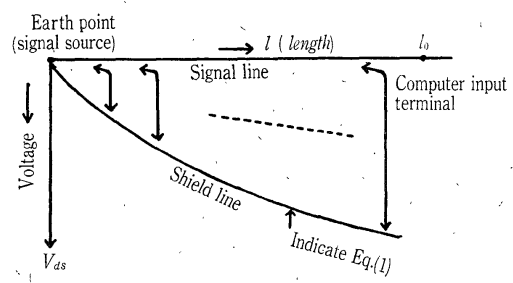

Fig. 3 Simplified signal line for inductive pick up

源から計算機入力端子まで一様に分布するとし, 計算 機入力端子で測定した $\mathrm{CMV}$ を $E_{c 1}$ とする. $E_{c 1}$ に より，しゃへい線〜大地間の漏洩インピーダンス $Z_{s g}$ を通して，しゃへい線の各点加少地へ電流が流れ， ての電流により, しゃへい線に電圧降下が生じる。い ま，信号線がしゃへい線により，大地と絶縁されてい るため，信号線〜大地間に電流が流れないあのとする と, 乙の電圧降下が，乙ゃへい線〜信号線間の電位差 $V_{d s}\left(l / l_{0}\right)$ となり, 信号源から長さ $l$ の点で（1）式 で表わされる2).

$$
V_{d s}\left(\frac{l}{l_{0}}\right)=\frac{R_{s} \cdot E_{c 1}}{2 Z_{s g}} \cdot\left(\frac{l}{l_{0}}\right)\left(1-\frac{1}{3} \cdot \frac{l^{2}}{l_{0}^{2}}\right)
$$

ただし， $R_{s}:$ しゃへい線の抵抗

$Z_{s g}$ : しゃへい線〜大地間の漏洩インピー ダンス

$l_{0}:$ 信号源から計算機入力端子までの信号 線の長さ

なお， $R_{s}, Z_{s g}$ は信号源から計算機入力端子まで一 様行分布するあのとする.

Fig. 3 亿示すように $V_{d s}\left(l / l_{0}\right)$ なる電位差の存在 によって，信号線〜しゃへい線間に，信号線の各点か ら, 信号線としゃへい線間の漏洩インピーダンスを通 して電流が流れる.乙の電流が信号線の抵抗を通って 電圧降下を生じ信号線の 2 線間の不平衡抵抗によっ 


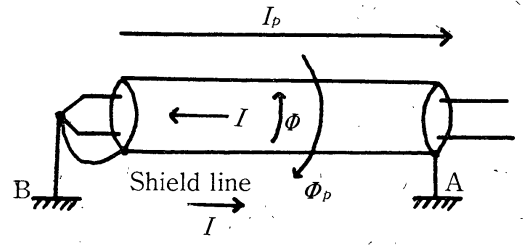

Fig. 4 Inductive pick up

て，(2) 式で表わされる 2 線間の電位差 NMV; $E_{n 1}$ が生じる (詳細は文献 2) 参照).

$$
E_{n 1}=R_{s} \cdot \Delta R \cdot K \cdot E_{c 1} / 8 Z_{s q} \cdot Z_{s s}
$$

ただし， $\Delta R:$ 信号線の不平衡抵抗

$K:$ フィルタの商用周波数での減衰定数

$Z_{s s}:$ しゃへい線〜信号線間の漏洩インピー ダンス

なお， $\Delta R, Z_{s s}$ は信号源から計算機入力端子まで一 様に分布するすのとする。

(2) 式は計算機入力端子より後段の影響を無視した あのである.いま，計算機入力端子より後段の信号線 〜大地間の漏洩インピーダンスを $Z_{s b}$ とする. $Z_{s b}$ は, 主にほかの入力スキャナの開時における漂游容量 および漏洩抵抗によるむのであり，信号線の対地イン ピーダンスを低下させている， $Z_{s b}$ の影響を考慮ずる と, NMV; $E_{n 1}{ }^{\prime}$ は（3) 式で表わされ; $E_{c 1} / E_{n 1}{ }^{\prime}$ が1点接地しゃへいの CMRR となる2).

$$
E_{n 1}{ }^{\prime}=\left\{\frac{R_{s} \cdot \Delta R \cdot K}{8 \cdot Z_{s g} \cdot Z_{s s}}+\frac{\left(\Delta R+\Delta R_{f}\right) K+\Delta R_{b}}{Z_{s b}}\right\} E_{c 1}
$$

ただし， $\Delta R_{f}$ : フィルタの不平衡抵抗（フィルタに 使用される抵抗の偏差が零でないこ とにより生じる. Fig.1 参照)

$\Delta R_{b}:$ フィルタの出口から入力增幅器まで の不平衡抵抗

な挍， $\Delta R_{f}^{\prime}, \Delta R_{b}, \quad Z_{s b}$ は集中定数とみなしてよ い.

（3）式で表わされる1点接地しゃへいは電磁しゃへ いの効果がないので, 熱電対入力のように信号電圧が 数 $\mathrm{mV}$ と低く電磁誘導による $\mathrm{CMV}$ が大きなシステ ムでは精度上，問題になる，電磁誘導は Fig. 4 亿示 すように，電力線に流れる電流 $I_{p}$ によって生じる単 位長あたりの磁束を $\Phi_{p}$ とすると, しゃへい線, 信号 線の単位長あたり（4) 式で表わされる電圧 $V$ が発 生するて之によって起てる。

$$
V=\partial \Phi_{p} / \partial t
$$

しゃへい線が 2 点接地であると，(4)式の $V$ によ って $\mathrm{A} \rightarrow$ しへい線 $\rightarrow \mathrm{B} \rightarrow \mathrm{A}$ と大地州路を通して $\Phi_{p}$ の変化を打消す方向に電流 $I$ が流れ，しゃへい線に単

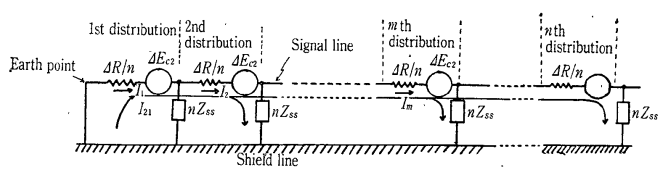

Fig. 5 Effect of inductive pick up in the signal line with 2 points earth shield line

位長あたり $\Phi$ の磁束が生じ，乙れによって電磁しゃ へいの効果が現われる. 信号線への誘起電圧は (5) 式のようになり，しゃへい率入は（6)式で定義され る.しゃへい線として電磁シールド・テープや, 硬スチ ールのコンジットを使用すると， $\lambda=0.1 \sim 0.01^{4), 6) \sim 8)}$ 程度である.

$$
\begin{aligned}
& v=\partial \Phi_{p} / \partial t-\partial \Phi / \partial t \\
& \lambda=v / V
\end{aligned}
$$

つぎに，2 点接地しゃへいの場合の $\mathrm{CMV} ; E_{c 2}$ と $\mathrm{NMV} ; E_{n 2}$ の関係を求める. まず; 計算機入力端子 より信号源側について考える. 電磁誘導による信号線 の電圧分布状態をつぎの前提のもとで解く．しゃへい 線には大地帰路の閉回路によって電流が流れるが，し ゃへい線が信号源之計算機入力端子で 2 点接地され, しゃへい線の抵抗 $R_{s}$ ，信号線の抵抗 $R$ の関係が $R_{s}$ 《R なので $R_{s}$ による電圧降下を無視する． 2 点の 電位が同じであると仮定すると，しゃへい線の電位が 2 点間で一定であるといえる.

電磁誘導による電圧が信号源から計算機入力端子ま で一様に分布するとし，先端の接地点（信号源）から 入力端子までを $n$ 等分 $(n \rightarrow \infty)$ し, 電磁誘導による 電圧によって信号線に流れる電流の状態を微視的にみ れば Fig.5のようになる。ただし，Fig. 5 は2本で 構成される信号線間の抵抗值の差 $\Delta R$ (不平衡抵抗) のみを取出している. 細分化された誘起電圧でとに重 ねの理を用いて Fig. 5 の電流分布の状態を解く.

'Rに流れる電流は信号線〜しゃへい線間の漏洩イン ピーダンス $Z_{s s}$ を通って，信号線〜しゃへい線間流 れる． $Z_{s s}, \quad R$ は信号源より計算機入力端子まで一様 に分布するすのとする，乙こで CMV; $E_{c 2}$ による $\Delta R$ 上での電圧分布は 2 線間の不平衡抵抗上の電圧分布で あるので，これを計算機入力端子のところでみれば， これが NMV； $E_{n 2}$ となる。

Fig. 5 において，細分された誘起電圧を接地点から 順に第 1 分布; $\cdots . . .$. 第 $n$ 分布とする之, 各誘起電圧ご との各分布を流れる電流 $i_{11}, i_{12}, \cdots i_{1 n}, i_{21}, i_{22} \cdots \cdots$ は $Z_{s s} \gg R$ なので（7）式で表わされる.

$$
\begin{aligned}
& i_{11}=n \Delta E_{c 2} / n Z_{s s}, \\
& i_{12}=(n-1) \Delta E_{0} / n Z_{s s} \\
& \vdots \vdots \\
& i_{1 n}=\Delta E_{c 2} / n Z_{s s}
\end{aligned}
$$




$$
\begin{aligned}
& i_{m 1}=i_{m 2}=\cdots i_{m m}=(n-m+1) \Delta E_{c 2} / n Z_{s s} \\
& \vdots \\
& i_{m n}=\Delta E_{c 2} / n Z_{s s}
\end{aligned}
$$

ただし， $i_{i j}: i$ 分布にある $\Delta E_{c 5}$ により $j$ 分布に 流れる電流

第 1 分布から第 $n$ 分布までの誘起電圧により, 各分 布ごとに流れる電流の和を $I_{1}, I_{2}, \cdots I_{n}$ とすると, これが，信号線の各分布に流れる電流であり，（8)式 で表わされる. $I_{1}, I_{2}, \cdots, I_{n}$ ，それぞれと各分布の $\Delta R / n$ により 2 本の信号線間に電圧降下差が生じ，乙 れが NMV となる. $\Delta R$ 上の電圧降下として第 1 分 布から第 $m$ 分布までの電圧降下 $V_{s s}(m / n)$ を求める と（9）式のようになる（9)式は CMV； $E_{c 2}$ によ って生じる $m$ 分布点での信号線 2 本の間の電位差を 表わす。

$$
\left.\begin{array}{c}
I_{1}=\sum_{m=1}^{n} i_{m 1}=n \Delta E_{c 2} / 2 Z_{s s} \\
\vdots \\
I_{n}=\sum_{m=1}^{n} i_{m n}=I_{n-1}-(n-1) \Delta E_{c 5} / n Z_{s s}
\end{array}\right\} .
$$

ここで計算機入力端子での NMV; $E_{n 2}{ }^{\prime}$ は $(9)$ 式 で $m=n$ とおいたもので（10）式で表わされ，これに， フィルタの減衰定数 $K$ を考慮すると $E_{n 2}{ }^{\prime \prime}$ は (11) 式で表わされる。

$$
\begin{aligned}
& E_{n 2}{ }^{\prime}=\Delta R \cdot E_{c 2} / 3 Z_{s s} \\
& E_{n 2}{ }^{\prime \prime}=\Delta R \cdot E_{c 2} \cdot K / 3 Z_{s s}
\end{aligned}
$$

ただし， $E_{n 2}{ }^{\prime}$ : 計算機入力端子より後方の影響を無 視した場合の入力端子でのNMV(フ ィルタの入力 NMV)

$E_{n 2}{ }^{\prime \prime}: E_{n 2}{ }^{\prime}$ がフィルタを通過後, 減衰した あの (フィルタの出力 NMV)

NMV; $E_{n 2}$ を求めるには，(11）式が計算機入力端 子より後段の信号線〜大地間の漏洩インピーダンス, $Z_{s b}$ の影響を無視したあのであるので，てれの影響を 考慮に入れるととが必要である.

$Z_{s b}$ は増幅器のすぐ前に集中して存在するとみなさ れ， $E_{c 2}$ は信号源から計算機入力端子までで発生して いるので計算機入力端子のところでは集中定数とみな され, $\Delta R_{f}, \Delta R_{b}$ あ信号線に比べて距離の短いとこ ろに存在するので集中定数とみなされる. $E_{c 2}, \Delta R_{b}$, $Z_{s b}$ による NMV はフィルタの後段で生じたあのな のでフィルタによる減衰が得られない.

したがって, $E_{c 2}, Z_{s b}, \Delta R, \Delta R_{f}, \Delta R_{b}$ 亿よる NMV は Fig. 6 の計算機入力端子より後段の等価回

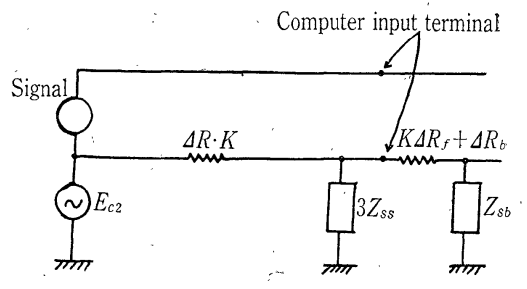

Fig. 6 Equivalent circuit of signal line for inductive pick up, with 2 points earth shield line

路で表わされ， $E_{n 2}$ は (12) 式のように表わされる.

$$
E_{n 2}=\left\{\frac{\Delta R \cdot K}{3 Z_{s s}}+\frac{\left(\Delta R+\Delta R_{f}\right) K+\Delta R_{b}}{Z_{s b}}\right\} E_{c 2}
$$

ただし， $E_{c 2}=\lambda E_{c 1}$

(3) 式ど (12) 式において, $Z_{s s \cong 10^{6} \sim 10^{7} j \Omega, Z_{s g}}$ $=10^{6} \sim 10^{7} \mathrm{j} \Omega, \lambda=0.1 \sim 0.01, R_{s} \cong 10 \Omega$ とし第 1 項 を比較すると, $R_{s} \cdot \Delta R \cdot K /\left(8 Z_{s s} Z_{s q}\right) \ll \Delta R \cdot K \cdot \lambda /$ $3 Z_{\text {ss }}$ となり，2点接地しゃへいのほうが CMRR は 小さく, NMV は大きいととがわかる.

以上（3)式之（12）式の比較から，しゃへい線の 信号源 1 点接地は，信号源と計算機入力端子での 2 点 接地方式より CMRR が大きく, (5)式と Fig.4より 電磁しゃへいの効果がないととがわかる. 1 点接地し ゃへいと 2 点接地しゃへいの長所を取入れて，電磁誘 導の大きいところでは Fig.1 のBグループのように， 2 重しゃへい線を使用し，内側しゃへい線を信号源で 1 点接地し, 静電しゃへいの効果と CMRR の増大を 目的とし，外側しゃへい線を信号源と計算機入力端子 で 2 点接地することによって電磁しゃへいの効果を表 わす 2 重しゃへい混合接地方式を提案する， 2 重しゃ へい混合接地方式の $\mathrm{CMV} ; E_{c 3}$ と $\mathrm{NMV} ; E_{n 3}$ の関 係は，(12)式を導いたときと同じに外側しゃへい線を アース電位とみなせば（3）式と同じ形で（13）式の ようになる。

$$
E_{n 3}=\left\{\frac{R_{s} \cdot \Delta R \cdot K}{8 Z_{i 0} \cdot Z_{i s}}+\frac{\left(\Delta R+\Delta R_{f}\right) K+\Delta R_{b}}{Z_{s b}}\right\} E_{c 3}
$$

ただし， $Z_{i 0}$ ：内側しゃへい線と外側しゃへい線間 の漏洩インピーダンス

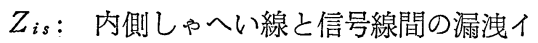
ンピーダンス

$E_{c 3}=\lambda E_{c 1}$

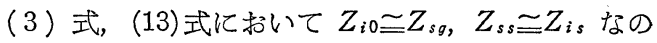
で電磁しゃへいの効果分 $\lambda$ だけ， $E_{n 3}$ が $E_{n 1}$ より小 さくなり，2 重しゃへい混合接地方式の効果がわかる: ただし， 2 重しゃへい構造のケーブルは高価なので, 強い電磁誘導源をむつ場合にのみ使用することを考慮 

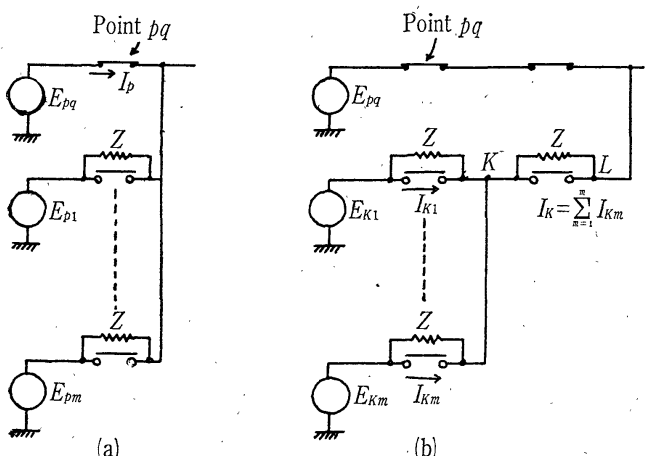

Fig. 7 Effect of block switches

する必要がある。

\section{3. ブロック・スイッチの効果}

医Fig. 1 亿示すように，各入力選択のためのスキャナ をいくつかまとめて, 1 個のグループを構成し, 各グ ループでとにブロック・スイッチを入れている.

入力点の多いシステムでは，スキャナ開時の漏洩イ ンピーダンス（例: 水銀リレー1 個あたり， $700 \mathrm{M} \Omega$ 程度)が並列に存在し，信号源が接地されているため; 信号線〜大地間の漏洩インピーダンス $Z_{s b}$ が低下す る. ブロック・スイッチを設けるととにより $Z_{s b}$ を大 きくし CMRR を大きくするととができる（例：

Fig. 7 (b) のK 点で信号線〜大地間のインピーダ ンスは $Z / m$ で $L$ 点では $(Z / m)+Z$ となり, ブロッ ク・スイッチによって $(1+m)$ 倍のインピーダンスと なる)。 また $Z_{s b}$ にょって NMV に変換されたむの の1部 ( $\Delta R_{b}$ によって CMV が $\mathrm{NMV}$ 亿変換され たもの：(3)，(12)，(13)式参照）はフィルタによっ て除去できないので $Z_{s b}$ を大きくすることが必要沈 る.

以下，ブロック・スイッチの効果について検討する.

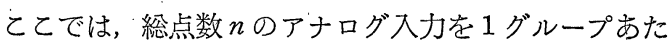
り， $m$ 個の入力とし， $r$ 個のグループに分けた場合 の CMRR への影響を算出し，何点でとにブロック・ スイッチを入れるべきかを示す（すなわち $n=m r$ ）.

Fig. 7 に示すように, 各スキャナが漏洩インピーダ ンス $Z$ をむっているとする. いま, がグループの $q$ 番目のスキャナが選択され，ての CMVを $E_{p q}$ とし， 同じグループの各点の $\mathrm{CMV}$ を，それぞれ， $E_{p 1}, \cdots$ $E_{p m}$ とすると，乙れらの CMV により， $p q$ 点に流 れる電流 $I_{p}$ は (Fig.7 (a) 参照)，(14）式のように なる.

$$
I_{p}=\left(m E_{p q}-\sum_{m=1}^{m} E_{p m}\right) / Z
$$

つぎに, $K$ グループ $(K \neq p)$ から， $p q$ 点に流れ る電流 $I_{K}$ は $K$ グעープの CMV をそれぞれ, $E_{K 1}$, $\cdots, E_{K m}$ とすると (Fig.7 (b) 参照)，(15) 式のよ うになる。

$$
I_{K}=\left(m E_{p q}-\sum_{m=1}^{m} E_{K m}\right) / Z(1+m)
$$

こてで, pグループ以外のすべてのグループから流 れる電流は（15）式より（16）式のようになる.

$$
\sum_{\substack{K=1 \\(K \neq p)}}^{r} I_{K}=\sum_{\substack{K=1 \\(K \neq p)}}^{r}\left\{\frac{m E_{p q}-\sum_{m=1}^{m} E_{K m}}{Z(1+m)}\right\}
$$

$p q$ 点汇流れる電流 $I_{p q}$ は (14), (16) 式から (17) 式のようになる.

$$
\begin{gathered}
I_{p q}=I_{p}+\sum I_{K}=\frac{m E_{p q}-\sum_{m=1}^{m} E_{p m}}{Z} \\
+\sum_{\substack{K=1 \\
(K \neq p)}}^{r}\left\{\frac{m E_{p q}-\sum_{m=1}^{m} E_{K m}}{Z(1+m)}\right\}
\end{gathered}
$$

いま，入力選択点 $p q$ の CMV; $E_{p q}$ に着目し,非 選択スキャナの各点に存在する CMV の影響がないと 考え， $\Sigma E_{K m} \fallingdotseq 0, \Sigma E_{p m} \fallingdotseq 0$ と仮定すると（17）式は (18)式となる.

$$
I_{p q}=m(r+m) E_{p q} / Z(1+m)
$$

なお，スキャナの漏洩インピーダンスの原因による $\mathrm{CMV}$ から $\mathrm{NMV}$ への変換の関係は (3), (12), (13) 式の第 2 項で表わされている.ブロック・スイッチの ない場合， $I_{p q}$ は (19) 式で表わされ，ブロック・ス イッチを使用した 1 点接地しゃへいの場合の, NMV, CMV の関係は (3)，(18)，(19) 式より (20) 式で 表わされる.

$$
\begin{aligned}
I_{p q}= & E_{p q} / Z / n, \text { ただし, }\left\{\begin{array}{l}
Z / n=Z_{s b} \\
n=m r
\end{array}\right. \\
E_{n A}= & {\left[\frac{R_{s} \cdot \Delta R \cdot K}{8 Z_{s g} \cdot Z_{s s}}\right.} \\
& \left.+\frac{m(r+m)\left\{\left(\Delta R+\Delta R_{f}\right) K+\Delta R_{b}\right\}}{Z(1+m)}\right] E_{p q}
\end{aligned}
$$

ここで; $m(r+m) /(1+m)<n$ なので $(3),(19)$, (20)式よりブロック・スイッチの効果が表わされてい るととがわかる.ブロック・スイッチの効果を最大に し, NMV を最小にするには $n=m r$ の関係を利用し (18) 式の $m(r+m) /(1+m)$ を最小にするように 1 グ ループあたりの点数 $m$ と総点数. $n$ の関係を求め; ブ ロック・スイッチの配分をすることが必要である.

(21) 式の $m$ と $n$ の関係が成立するとき，NMVを 
ブロック・スイッチの効果として最小にすることがで きる。

$$
\dot{m}=-1+\sqrt{1+n} \text { ただし, } n=m r
$$

しかし，アナログ入力の総点数 $n$ はシステムごとに 変わり，また，ハードウェア実現上， $2^{X}(X:$ 正整数 $)$ 単位でブロック分けすることが望ましい. Table 1 亿 光と $m=2^{x}$ とした場合に (18)，(21) 式より求めた アナログ入力総点数と最適配分点数の関係を示す.

\section{4. 入力増幅器の時定数}

アナログ入力増幅器の時定数は計算機クロック・パ ルスからの誘導電圧，スキャナ・リレーの接点雑音， 半導体スキャナの駆動トランスの逆方向跳㸚返り雑 音, 駆動波形の漂游容量を通しての雑音などの周波数 の高い雑音を除去するために適当に遅くしておく必要 がある. 增幅器の時定数が遅いと, スキャニング速度 が制限される. 増幅器の時定数をこてではステップ入 力電圧 $E_{s}$ を加えてから出力が $E_{s}\left(1-e^{-1}\right)$ に達する までの時間と定義する。

\section{1 スキャニング速度と増幅器の時定数}

Fig. 8 亿示すように,スキャナを閉にする駆動信号 がでてからスキャナが完全に“閉”状態になるまでに, スキャナ・リレーの動作時間，半導体スキャナ駆動の ためのパルス・トランスの遅れなどによって，遅延時 間 $t_{0}$ が存在し，同じように，“閉” 状態から“開” 状 態への移行にも遅延時間 $t_{r}$ が存在する. 通常 $t_{0} \neq t_{r}$ である.いま, $U_{V}$ を $\mathrm{AD}$ 変換の最小単位電庄の入 力換算值, $V_{f}$ を入力のフル・スケール電圧, $S_{c}$ をス キャニング速度，てを増幅器を 1 次遅れ系としたとき の時定数とすると, $U_{V}>V_{f}-V_{f}\left(1-e^{-t / \tau}\right)$ のときに $\mathrm{AD}$ 変換を開始してよいととになる. $V_{f}$ が加えられ てから, $\mathrm{AD}$ 変換を開始するまでの最大許容時間は $\left(1 / s_{c}-t_{0}-t_{1}\right)$ であるので， $\tau$ は (22) 式を満足せね ばならない。

$$
\begin{aligned}
& U_{V} / V_{f}>\exp \left\{\left(T_{e r}-1 / s_{c}\right) / \tau\right\} \\
& \text { ただし, } T_{e r}=t_{0}+t_{1} \\
& t_{1}>\left(t_{r \max }-t_{0 \min }\right) \text { あるいは }\left(t_{0 \max }-t_{r \min }\right)
\end{aligned}
$$

\section{2 クロック・パルスの誘導電圧と増幅器の時定 数}

計算機では各駆動回路にクロック・パルスが供給さ れており，その周波数む高いため, クロック・パルス 電流によって，アナログ入力信号線に誘起される電圧 はかなり大きなむのになる，また，アナログ入力信号 線はスキャナのあと，共通線を経て増幅器に入る．そ のため，乙の箇所にしゃへい線を用いて，接地すると 2 点接地之等価になり，信号線〜大地間のインピーダ
Table 1 Optimum number of points for block switches

\begin{tabular}{c|c}
\hline \hline $\begin{array}{l}\text { numbers of point every } \\
\text { one block switch }\left(2^{X}\right)\end{array}$ & total points of analog inputs \\
\hline 128 & more than 8,384 \\
64 & $2,144 \sim 8,384$ \\
32 & $528 \sim 2,144$ \\
16 & $132 \sim 528$ \\
8 & $44 \sim 132$ \\
4 & $12 \sim 44$ \\
2 & $5 \sim 12$ \\
\hline
\end{tabular}

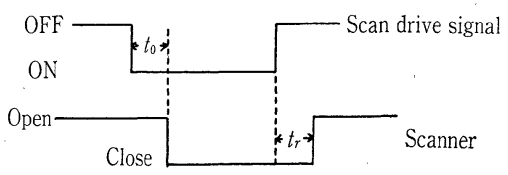

Fig. 8 On-time and off-time of scanner

ンスが小さくなり，CMRR が小さくなるので望まし くない，したがって，共通線は裸線を用いることにな り,クロック・パルス電流による誘導電圧をしゃへい するととができない。

Fig. 9, 10 亿, 電圧 $13.5 \mathrm{~V}$, 電力 $200 \mathrm{~W}$, 周波数 $250 \mathrm{kHz}$ のクロック・パルスをもつ，クロック同期式 計算機において計算機入力端子で 2 本の信号線を短絡 し，接地した場合，スキャナを閉じて，増幅器の入力， で測定したクロック・パルスによる信号線への誘導に よって生じた CMV, NMV の例を示す. Fig.9 の大 きな山と山との間が，クロック・パルス間の幅に相当 する. Fig. 10 の NMV はクロック・パルスの 1 周期 ごとに表われる大きな山が目立つが，ほぼ正弦波に近 似できる形になっている，入力増幅器の時定数を遅く しておけば，乙の雑音を十分除去することができる. 増幅器の設定時間 $\tau$ と,クロック・パルスによる $\mathrm{NMV}$ の最大值 $E_{C N}$ は (23) 式を満足しなければな らない，ただし，NMV は周波数 $f_{c}$ の正弦波で近似 した.

$$
U_{V}>\left|E_{C N} /\left(1+2 \pi f_{c} \tau j\right)\right|
$$

\section{3 スキャナ雑音と増幅器の時定数}

スキャナ・リレーの接点雑音（リレー接点が磁界の 中を運動するととにより発生する), 半導体スキャナの 駆動パルス・トランスのインダクタンスの 1 次 2 次 間の漂游容量によるスキャナ雑音などによって，スキ ヤナが “閉”になったとき，信号線に雑音電圧が発生 する，乙の雑音による NMV; $E_{C N}$ は通常(24) 式で 示すように，減衰振動の形で近似される.

$$
E_{C N}=E_{c} \exp \left(-t / \tau_{R}\right) \sin \beta t
$$

ただし， $\tau_{R}$ : 減衰定数， $\beta$ : 雑音の角周波数 


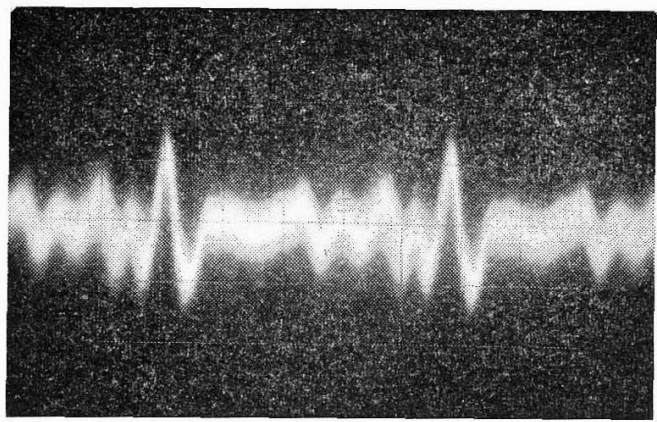

Fig. 9 Example of common mode voltage induced by clock pulse

增幅器が 1 次逑れ系とし，その時定数を $\tau$ とすると 角周波数 $\beta$ に対する利得は $|1 /(1+j \beta \tau)|$ ， スキャナ が閉じて信号が堌幅器に加えられてから， $\mathrm{AD}$ 变換を 開始するまでの時閒は $\left(1 / s_{c}-T_{e r}\right)$ であり，そのとき の $E_{C N}$ の振幅は (24) 式より $E_{c} \cdot \exp \left\{\left(T_{e r}-1 / s_{c}\right)\right.$ $\left\{\tau_{R}\right\}$ となる。

クロック・パルスによる誘導電圧が増幅器の入力で UV より小になるには（25）式を満足しなければなら ない。

$$
U_{V} / E_{c}>\exp \left\{\left(-1 / s_{c}+T_{e r}\right) / \tau_{R}\right\} \cdot|1 /(1+j \beta \tau)|
$$

以上の (22), (23), (25) 式より增幅器の時定数の 範囲を決定することができる.

\section{5. あとがき}

以上，制御用計算機のアナログ入力における CMV の精度に及ぼす影響と精度に関する 2〜3 の検討を行 った．とれらの検討によりつぎのととが結論づけられ る.

（1）アナログ入力信号線のしゃへい方式としては 信号源で信号線としゃへい線を 1 点接地するJ式が， 電磁しゃへい效果のある2 点接地しゃへい方式より CMRR が大きく，NMV が小さい，また，霞磁誘導 によるCMV の大きい所では 2 重しゃへい混合接地方 式がよいが，経済的に見合わない場合，1.部に 2 重し やへい線を用いてむ効果がある.

（2）ブロック・スイッチの分割点数はアナログ入 力総点数によって暴なるが，一般に，1増幅器あたり のアナログ入力点数は 512 点, 1,024 点, 2,048 点程 度なのでそれぞれ，16 点，32 点，32 点でとにブロッ ク・スイッチを入机るのが適当である.

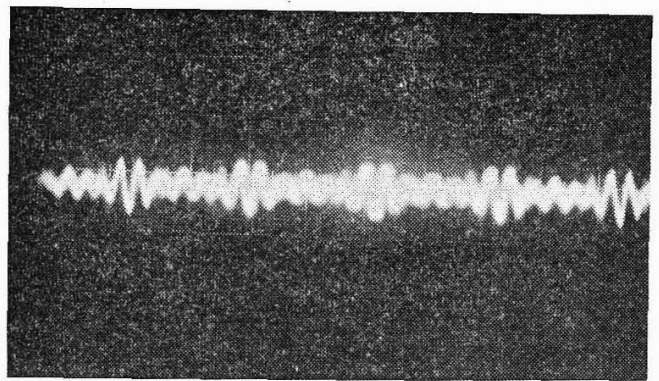

Fig. 10 Example of normal mode voltage converted from common mode voltage shown in Fig. 7

（3）增幅器の時定数は所要スキャニング速度より 最大許容值が, クロック・パルスによる誘導雑音, ス キャナ雑音除去の目的から最小訢容值が求まる。この 問題は実装上の問題が雑咅の大きさに，かなり影響を 与えるので, システムごとの実測による設定が必珐で CPU が別のすのになれば， て あ異なってくる可能性 がある。

以上の結論は，スキャナがトランジスタや FET な ぞの半導体の場合にあ適用できる，また，アンプの仕 様決定, システムの CMRR 特性の推定，スキャナ構 成の決定をするととによって, 制御用計算機のアナロ グスカシステムの設阡，記録計のようなアナログ信号 のスキャナをむつシステムの設計，使用ケーブルの決 定，配線計画の必要となる計算制御システムの工事計 画, プラント計装，システムの設䛨，計画などに役立 つあのである.

\section{参 考 文 献}

1）井上：プロセス・コンピュータ，電気学会全国大会， $S$ 10-2 (1971)

2）五十嵐，仁田：制御用計算機におけるアナログ入力信号 線の等価回路，計測自動制御学会論文集，1-2，139/145 (1965)

3) R. Morrison: Protecting Signal Circuits by Grounding and Shielding, Instrumentation Technology, 33/36 (1973)

4) B.E. Klipec: Reducing Electrical Noise in Instrument Circuit, IEEE Trans. on IGA, IGA-3-2 (1967)

5) J. Jursik: Rejection Common Mode Noise in Process data System, Control Eng., 10-8, 61/66(1963)

6）森定, 新谷, 赤沢：鋼带の磁気特性に基づくしゃへい係 数の一計算法, 電四連大, 1916 (1965)

7）森脇，森定，前田：電磁しゃへいケーブルの中間接地・ 分布接地について，電四連大，1915 (1965)

8）新谷: 高誘尊用電磁しゃへいケーブル飞閶する考察,大 日日本電線時報, 28, 30/36 (1965) 